\title{
The effects of $\alpha$-lactalbumin and whey protein concentrate on $\alpha$-amino acids, calcium and phosphorus levels in blood and gastrointestinal tract of rats
}

\author{
Odile T. Pantako, Jean Amiot \\ Dairy Research Center, Department of Food and Nutrition Sciences, \\ Faculty of Food and Agriculture Sciences, Laval University, Sainte-Foy, Québec G1K 7P4, Canada \\ (Received 17 February 2001; accepted 5 May 2001)

\begin{abstract}
The effects of two dietary proteins on $\alpha$-amino acids, calcium and phosphorus concentrations in plasma, stomach and intestine were investigated in rats trained to consume, in a single two-hour daily meal, diets containing $\alpha$-lactalbumin ( $\alpha$-la) or whey protein concentrate (WPC) for two weeks. The results indicated that the concentrations of calcium and phosphorus in the gastrointestinal tract and that of $\alpha$-amino acids in portal vein were not significantly influenced by the nature of diets. The amount of $\alpha$-amino acids in the gastrointestinal tract of rats fed on WPC diet was significantly $(p<0.001)$ higher than that of $\alpha$-la group. The levels of insoluble calcium and insoluble phosphorus in the small intestine were significantly $(p<0.001)$ higher in $\alpha$-la group than in WPC group. These results indicated that the kinetics of $\alpha$-amino acids, calcium and phosphorus were differently influenced by the nature of diet ingested, the sampling time and the sites of sample collections.
\end{abstract}

$\alpha$-lactalbumin / whey protein / $\alpha$-amino acid / calcium phosphorus / digestion

Résumé - Effets de l' $\alpha$-lactalbumine et d'un concentré de lactosérum sur les teneurs en acides $\alpha$-aminés, en calcium et en phosphore dans le plasma et le tube digestif chez les rats. Les effets de protéines alimentaires sur les teneurs en acides $\alpha$-aminés, en calcium et en phosphore dans le plasma et le tube digestif ont été étudiés chez des rats alimentés pendant deux semaines selon des régimes contenant de l' $\alpha$-lactalbumine ( $\alpha$-la) ou un concentré de lactosérum (WPC). Les concentrations de calcium et de phosphore solubles dans le tube digestif et celles des acides $\alpha$-aminés dans la veine porte, étaient comparables pour les deux groupes étudiés. En revanche, la quantité d'acides $\alpha$-aminés dans le tube digestif des rats du groupe WPC était significativement $(p<0,001)$ supérieure. Les niveaux de calcium et de phosphore insoluble dans le tube digestif des rats du groupe $\alpha$-la étaient significativement $(p<0,001)$ plus élevés. Ces résultats montrent que les profils des acides $\alpha$-aminés, du calcium et du phosphore solubles dans le tube digestif étaient différemment influencés par la nature protéique du régime ingéré, le temps et les sites d'échantillonnage.

$\alpha$-lactalbumine / protéines de lactosérum / acide $\alpha$-aminé / calcium / phosphore

* Correspondence and reprints

E-mail: Jean.Amiot@aln.ulaval.ca 


\section{INTRODUCTION}

It is generally recognized that the use of milk and milk products to feed growing animals enhance calcium utilisation and bone mineralization. The high biological availability of calcium of milk and milk products has been related to their high calcium density and to other milk constituents which are thought to increase the bioavailability of calcium [36]. Lactose is recognized to enhance the passive diffusional calcium absorption, probably by modifying the mucosal intestinal cells permeability [46]. Phosphopeptides formed during casein peptic and tryptic digestion can also increase calcium absorption by preventing the formation of insoluble calcium phosphate complexes in the small intestine $[35,36]$. Whey proteins and fractions, $\alpha$-la and $\beta$-lactoglobulin ( $\beta$-la) have also the property to bind calcium and to enhance calcium absorption [21].

Whey proteins have been also shown to increase bone strength and collagen-specific amino acids such as hydroxyproline in ovariectomized rats [42]. Takada and his colleagues [43] observed that some active components of whey proteins having molecular weight ranging from 10000 to 23000 daltons, are able to suppress osteoclast-mediated bone resorption and osteoclastic cell formation. These active components of whey protein also improve osteoblast cell proliferation and differentiation [41]. The overall calcium-binding capacity of $\beta$-la in model solutions between $\mathrm{pH} 3.5$ and 7.0 and ionic strength of 0.04 to $0.16 \mathrm{M}$, is about half of that reported for $\alpha$-la [30]. $\alpha$-la is recognized as a calcium binding protein or calmodulin-like protein. Like other proteins having a calcium binding sites such as parvalbumin, troponin $\mathrm{C}$ intestinal calciumbinding proteins and calmodulin [40], $\alpha$-la possesses an unique $\alpha$-helical bend with carboxyl groups and oxygen donor ligands forming an octahedral calcium coordination site called EF hand [5, 6]. $\alpha$-la is thought to bind several other calcium-like cations known to substitute for this metal ion [7]. Besides this unique calcium binding site, $\alpha$-la contains at least one or two additional cation sites, each of which has restricted cations specificities. The strong calcium binding site is constituted of the carboxylate side chains of aspartic acid 82,87 and the carbonyl oxygens of residues 79 and 84 .

Various sources such as casein, whey and rapeseed are digested at different rates and release different proportions of peptides and free amino acids [18]. After ingestion of raw milk or pasteurized milk by the preruminant calves, $\alpha$-la is slowly but completely hydrolyzed in peptides by gastric enzymes within 3 hours and at $\mathrm{pH}$ under 3.5, whereas $\beta$-la is poorly or not at all attacked, even after 4 to $12 \mathrm{~h}[25,37,45]$. The resistance of $\beta$-la to digestives enzymes or microbial proteases has been related to the simultaneous presence of two disulfide bridges and one free thiol group that give a rigid structure conformation to this protein by allowing many exchanges between free $-\mathrm{SH}$ and the $\mathrm{S}-\mathrm{S}$ bonds known to enhance the stability of the molecule [8]. Pepsin, with specificity for tryptophan, tyrosine, phenylalanine, leucine and isoleucine [14], has no effect on these groups in native $\beta$-la because they are not accessible [33]. The three-dimensional structure of $\beta$-la overlaps in more than $95 \%$ and constitutes a hydrophobic pocket inside of eight stranded $\beta$-barrels bordered on one side by an $\alpha$-helix. This kind of $\beta$-barrel structure is thought to be a general structure device found in animal organism to trap and transport the small hydrophobic ligands such as fatty acids and vitamin A [29]. The resistance of this kind of protein to gastric digestion is an important requirement for the function of this retinol and fatty acids carrier-protein [31]. Furthermore, binding of fatty acids to $\beta$-la enhances the resistance and the conformational stability of the structure to tryptic digestion. However, the function of $\beta$-la as a physiological retinol carrier protein is found to be limited to the stomach and the upper small intestine [19]. 
Thus, the purpose of the present work is to compare the effects of in vivo digestion of WPC and $\alpha$-la on the concentrations of $\alpha$-amino acids, calcium and phosphorus in portal vein, stomach and the small intestine of rats fed with diets composed of these proteins.

\section{MATERIALS AND METHODS}

\subsection{Animals and diets}

Sixty Sprague-Dawley male rats (Charles Rivers, St-Constant, P.Q.) weighting 140-160 g have been individually housed in suspended wire stainless-steel cages. They were trained over one week to 12:12 hours light/dark cycle with a standard rat chow diet. Animals were cared for in accordance with the principles and guidelines of the Committee of Animals Care of Laval University. These guidelines have been formulated according to the principles and guidelines of the Canadian Council on Animal Care. The animals were then divided into two groups of thirty rats; each group was assigned to one of the experimental diets for two weeks (Tab. I). The protein contents of each diet have been adjusted to $20 \%$. The diets contained $0.5 \% \mathrm{Ca}, 0.4 \% \mathrm{P}, 5 \%$ fat, $2.43 \%$ lactose and $3.5 \%$ minerals mixture. Whey protein concentrate $(75 \%)$ were obtained from Saputo (Ste-Hyacinthe, Quebec, PQ) and $\alpha$-lactalbumin (90\%, 5.8\% moisture, $2 \%$ lactose and $2.2 \%$ residual minerals on dry basis) was obtained from Besnier Bridel (Laval, France). The composition of the crude protein source of $\alpha$-la was: $76 \% \alpha$-la; $4 \% \quad \beta$-la and included less than $5 \%$ serum albumin bovine. The whey protein concentrate was composed of $75 \%$ proteins, $9 \%$ lactose, $10 \%$ fat and $6 \%$ moisture. Animals were trained to consume at the same time every day, their total daily intake within a single 2-hour period, but had free access to water. After two weeks on experimental diets, rats were fasted for $24 \mathrm{~h}$ and refed on day 17 th prior sampling.
Table I. Composition of experimental diets (\% by weights).

\begin{tabular}{lcc}
\hline Ingredients & $\begin{array}{c}\text { Whey protein } \\
\text { concentrate }\end{array}$ & $\alpha$-lactalbumin \\
\hline Protein & 27.0 & 22.3 \\
Corn oil $^{1}$ & 2.3 & 5.0 \\
Cellulose $^{2}$ & 5.0 & 5.0 \\
Minerals mixture $^{3}$ & 3.1 & 3.4 \\
Vitamin mixture $^{4}$ & 1.0 & 1.0 \\
Choline bitartrate $^{5}$ & 0.2 & 0.2 \\
Lactose $^{6}$ & - & 2.3 \\
Corn starch $^{7}$ & 61.4 & 60.8 \\
Energy $_{\left(\mathrm{kcal} \cdot \mathrm{kg}^{-1} \text { diet) }\right.}$ & 3963.0 & 3800.0 \\
\hline
\end{tabular}

${ }^{1}$ Mazola corn oil, Best Foods, Canada Starch (Ontario).

${ }^{2}$ Alphacel nonnutritive bulk, ICN, Biochemical (Cleveland, OH, USA).

${ }^{3}$ AIN minerals mixture 76, INC Biochemical (Cleveland, OH, USA): $\mathrm{mg} \cdot \mathrm{kg}^{-1}$ diet of $\mathrm{Ca}, 5155$; $\mathrm{P}, 3983$; Na, 1020; K, 3600; Cl, 1570; Mg, 507; $\mathrm{Mn}, 53 ; \mathrm{Fe}, 34.65 ; \mathrm{Zn}, 31.5 ; \mathrm{I}, 0.2 ; \mathrm{Se}, 0.16$ and $\mathrm{Cr}, 2$. Mineral elements were supplied with $\mathrm{CaHPO}_{4}, \mathrm{NaCl}, \mathrm{Fe}$ citrate (16-17\%), $\mathrm{K}_{2} \mathrm{SO}_{4}$, $\mathrm{MgO}, \mathrm{MnCO}_{3}, \mathrm{ZnCo}_{3}, \mathrm{KIO}_{3}, \mathrm{Na}_{2} \mathrm{SeO}_{3} \cdot 5 \mathrm{H}_{2} \mathrm{O}$ and $\mathrm{CrK}\left(\mathrm{SO}_{3}\right) \cdot 12 \mathrm{H}_{2} \mathrm{O}$.

${ }^{4}$ AIN vitamins mixture 76A, INC Biochemical (Cleveland, OH, USA): $\mathrm{mg} \cdot \mathrm{kg}^{-1}$ diet of Thiamin$\mathrm{HCl}, 6.0$; Riboflavine, 6.0; Pyridoxine- $\mathrm{HCl}, 7.0$; Nicotinic acid, 30.0; D-calcium Pantothenate, 16.0; Folic acid, 2.0; Cyanocobalamin (Vit. B-12), 0.01; Retinyl Palmitate (Vit. A), 16.0; DL- $\alpha$-Tocopheryl Acetate, 200.0; Cholecalciferol (Vit. D3), 0.025, Menaquinone (Vit. K), 0.05.

${ }^{5}$ Choline bitartrate, Sigma (St-Louis, MO, USA).

${ }^{6}$ Lactose, Anachemia (Montreal, Canada).

${ }^{7}$ Corn Starch, ICN Biochemical (Cleveland, OH, USA).

Samples were taken in portal vein, stomach and intestine at 0 (fasted rats), 1, 2, 3, 4, and 5 hours after the onset of feeding. Five rats of each experimental diet group were anesthetized with isofurane (1.8\%). The abdominal cavity was then opened and the liver exposed. The portal vein was clamped about $0.5 \mathrm{~cm}$ from liver and about $2 \mathrm{~mL}$ of blood were drawn with a syringe for portal determination of calcium and phosphorus. To prevent bleeding, portal vein was clamped 
$1 \mathrm{~cm}$ from the collections site. Blood samples were immediately centrifuged and frozen at $-20^{\circ} \mathrm{C}$ until assayed. For the collections of samples in small intestine and in stomach, the gastrointestinal tract was ligated at the beginning of the stomach and at three positions in the small intestine as described by Lee et al. [23]. The stomach, the upper and lower intestinal contents were flushed out with ice-cold saline, homogenized and centrifuged to obtain soluble and insoluble fractions. All samples were lyophilized and stored at $-20^{\circ} \mathrm{C}$ until assayed.

\subsection{Analysis}

The nitrogen content of dietary protein sources has been evaluated with a Kjelfoss automatic 16210 apparatus (A/SN. Foss Electrical, Denmark). The energy content of diets has been assessed by an automatic adiabatic calorimeter (Parr 1241 Adiabatic Calorimeter, Moline, Illinois, USA). The $\alpha$-amino acids concentrations have been evaluated by a modified version of the OPA procedure described by Church et al. [9] and the results expressed as five amino acids equivalent (glutamic acid, glycine, leucine, lysine and serine). The diets and the gastrointestinal contents were wet-ashed with concentrated nitric acid (12 mL) and perchloric acid (3 mL). Plasma and ashed samples were diluted with $0.1 \mathrm{~N}$ hydrochloric acid solution before analyzed for calcium by atomic absorption spectrophotometry (Perkin-Elmer 603, Connecticut, USA) in lanthanum solution to a final concentration of $1 \%$. Total phosphorus contents of samples have been determined by the colorimetric method of Fisk and Subbarow [15].

All values were presented as means \pm SEM. Effects of dietary treatments, sampling times and sites were performed by analysis of variance with SAS [16] Student's t-test and Duncan's multiple range test were used for comparisons. The least squares means (LSMEANS) analysis was performed to evaluate the interactions differences between groups and within the groups. Data were considered significantly different at the level of $p<0.05$.

\section{RESULTS}

\subsection{The $\alpha$-amino acids}

Figure 1 shows the effects of the two milk protein sources on $\alpha$-amino acids levels in portal vein (Fig. 1A), stomach (Fig. 1B), upper (Fig. 1C) and lower small intestine (Fig. 1D). Although levels of portal $\alpha$-amino acids were quite similar for the two groups (Fig. 1A) those of rats fed on $\alpha$-la diet at $1 \mathrm{~h}$ and $2 \mathrm{~h}$ intervals were respectively 5 and $8 \%$ higher. Whatever the time of sample collections, the amount of $\alpha$-amino acids found in the stomach and upper intestine of rats fed on WPC diet was significantly $(p<0.001)$ higher than that of rats fed on $\alpha$-la group. These differences remained large until the end of the experiment. Endogenous (fasted state) $\alpha$-amino acids in stomach and the upper small intestine of rats fed with WPC diet were also significantly $(p<0.001)$ higher than those fed with $\alpha$-la diet. In contrast, differences in $\alpha$-amino acids levels in the lower small intestine were less pronounced between the two groups, except at fasted state and at 4-h time point where WPC group exhibited higher and significant $(p<0.05)$ mean values. These results suggested that compared to WPC diet, the digestion and absorption of $\alpha$-la diet were more rapid.

\subsection{Soluble and insoluble calcium}

Figures 2 and 3 illustrate the effects of digestion of $\alpha$-la and WPC on soluble and insoluble calcium levels in portal vein (Fig. 2A), stomach (Figs. 2B and 3A), upper (Figs. 2C and 3B) and lower small intestine (Figs. 2D and 3C). Soluble calcium levels in the gastrointestinal tract and portal vein were not significantly different between the two 
A

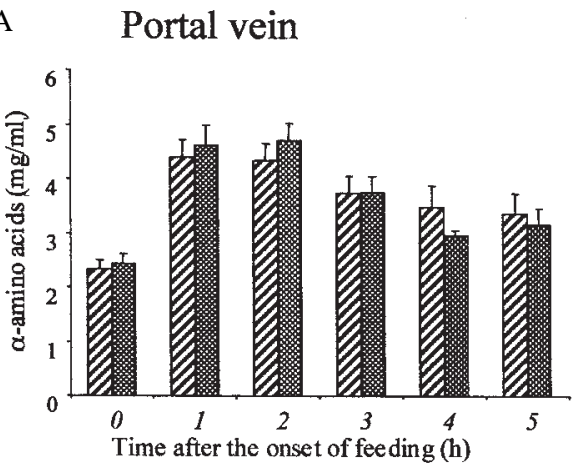

$\mathrm{C}$

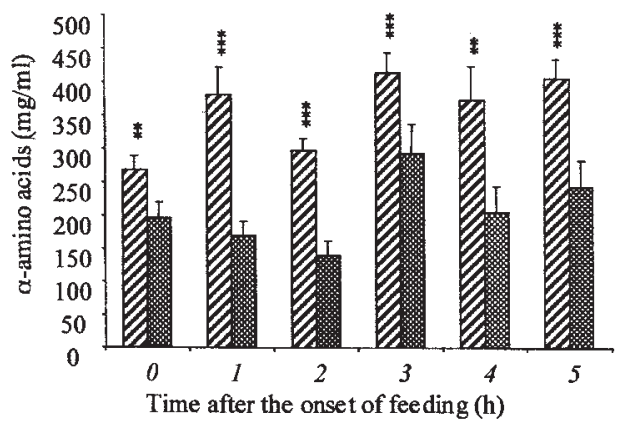

B

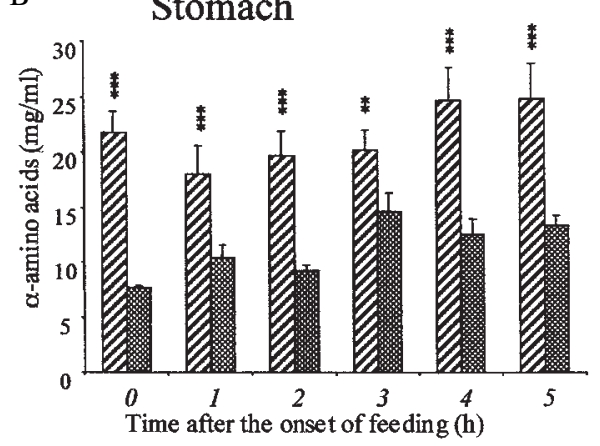

$\mathrm{D}$

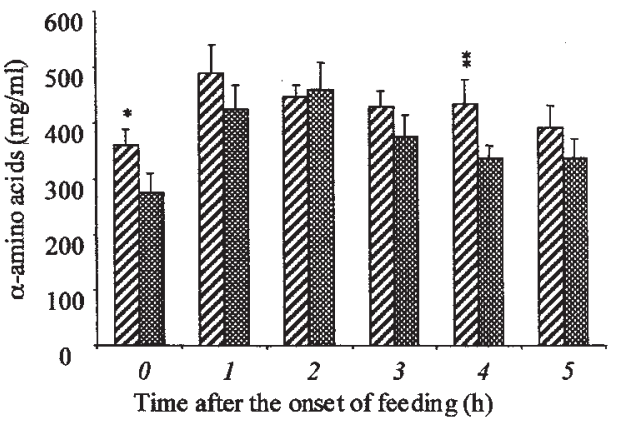

WII WPC

Figure 1. The effect of dietary protein digestion on $\alpha$-amino acids levels. Values are means \pm SEM. The number of rats in each time point was five. ${ }^{*} p<0.05$; ** $p<0.01$; *** $p<0.001$.

dietary groups. However, when considering soluble calcium at each time interval, the mean value at 3-h time point was significantly $(p<0.05)$ higher in the upper small intestine of rats fed $\alpha$-la diet (Fig. 2C). Although soluble calcium levels in portal vein (Fig. 2A) were similar for the two experimental groups, those of rats fed on $\alpha$-la diet at $1-h$ and 2 - $h$ intervals were respectively 7 and $2 \%$ higher.

Insoluble calcium levels were significantly $(p<0.001)$ influenced by dietary proteins, time and sites of sample collections. Compared to WPC group, the proportions of insoluble calcium in the upper small intestine of rats fed with $\alpha$-la diet were significantly $(p<0.001)$ higher at 0 -h, $4-\mathrm{h}$ and 5-h (Fig. 3B). Contribution of endogenous insoluble calcium secretions $(0-\mathrm{h})$ to total insoluble calcium in the stomach and the upper small intestine were also significantly $(p<0.001)$ higher in rats fed on $\alpha$-la diet (Figs. 3A and 3B). Also, compared to WPC group, rats fed with $\alpha$-la diet showed higher and significant $(p<0.005)$ insoluble calcium at 1-h, 2-h and 5-h time intervals in the lower small intestine (Fig. 3C).

\subsection{Soluble and insoluble phosphorus}

Figures 4 and 5 show the effects of the two dietary milk proteins on soluble and insoluble phosphorus levels in portal vein 

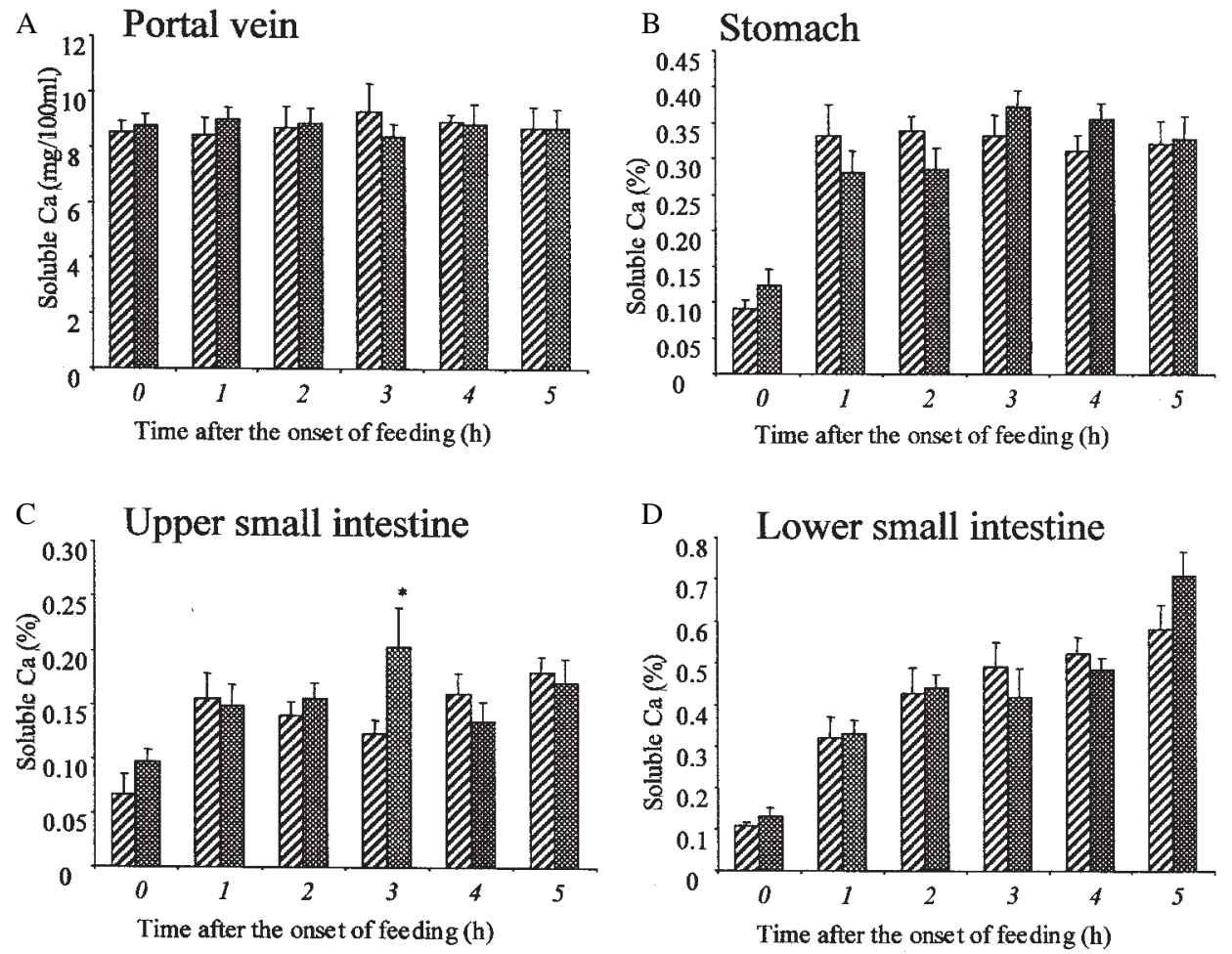

WII WPC

Figure 2. The effect of dietary protein digestion on soluble calcium levels. Values are means \pm SEM. The number of rats in each time point was five. $* p<0.05$; ** $p<0.01 ; * * * p<0.001$.

(Fig. 4A), stomach (Figs. 4B and 5A), upper (Figs. 4C and 5B) and lower small intestine (Figs. 4D and 5C). Levels of soluble and insoluble phosphorus in the two experimental groups were significantly $(p<0.001)$ affected by the nature of diet ingested, sampling time and sites of sample collections. Soluble phosphorus levels were comparable in portal vein for the two groups, except at 0 -h and 2-h time interval where WPC group showed a higher $(p<0.05)$ mean value. Compared to $\alpha$-la group, levels of soluble phosphorus in the stomach and upper small intestine of rats fed with WPC diet were significantly higher $(p<0.001)$ (Figs. 4B and $4 \mathrm{C}$ ). Soluble endogenous (fasted state) phosphorus levels were markedly higher in the gastrointestinal tract of rats fed with WPC diet than those fed with $\alpha$-la diet. The proportions of insoluble phosphorus in the stomach were similar for the two dietary groups (Fig. 5A). In contrast, compared to WPC group, insoluble phosphorus levels in the upper and the lower small intestine of rats fed on $\alpha$-la diet were significantly higher $(p<0.01)$ at 2-h, 4-h and 5-h time-points (Figs. 5B and 5C).

\section{DISCUSSION}

Rats fed on WPC have shown higher and significant $\alpha$-amino acids levels in their gastrointestinal tract. In an extensive study on 
QR WPC

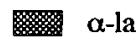

A

Stomach

B

\section{Upper small intestine}

\section{Lower small intestine}

Figure 3. The effect of dietary protein digestion on insoluble calcium levels. Values are means \pm SEM. The number of rats in each time point was five. $* p<0.05$; $* * p<0.01 ; * * * p<0.001$.

the protein digestion in human intestine as reflected in luminal, stomacal and plasma amino acid concentrations after meals, Adibi and Mercer [1] have found that the lack of a significant rise in the intraluminal concentrations of free amino acids after ingestion of protein is due to a rapid peptides absorption. This might be the case for rats fed with $\alpha$-la meal which have shown the lowest $\alpha$-amino acids levels in the stomach and in
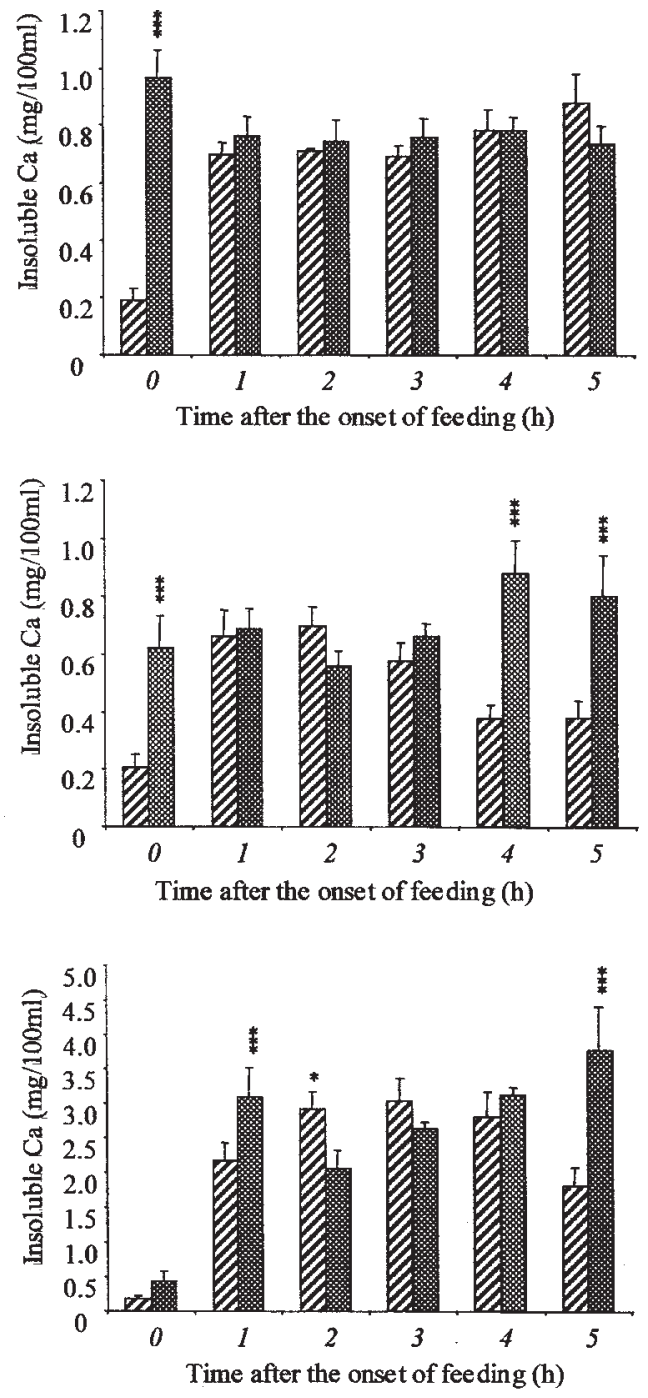

small intestine, and a higher although not significant, level of portal $\alpha$-amino acids after 1 and $2 \mathrm{~h}$ time intervals. Higher gastrointestinal $\alpha$-amino acids levels showed by WPC group would be explained by a longer retention time of dietary proteins in stomach, a slower rates to which the proteins were hydrolyzed and absorbed in the upper portion of the small intestine and to an higher endogenous intestinal secretions 

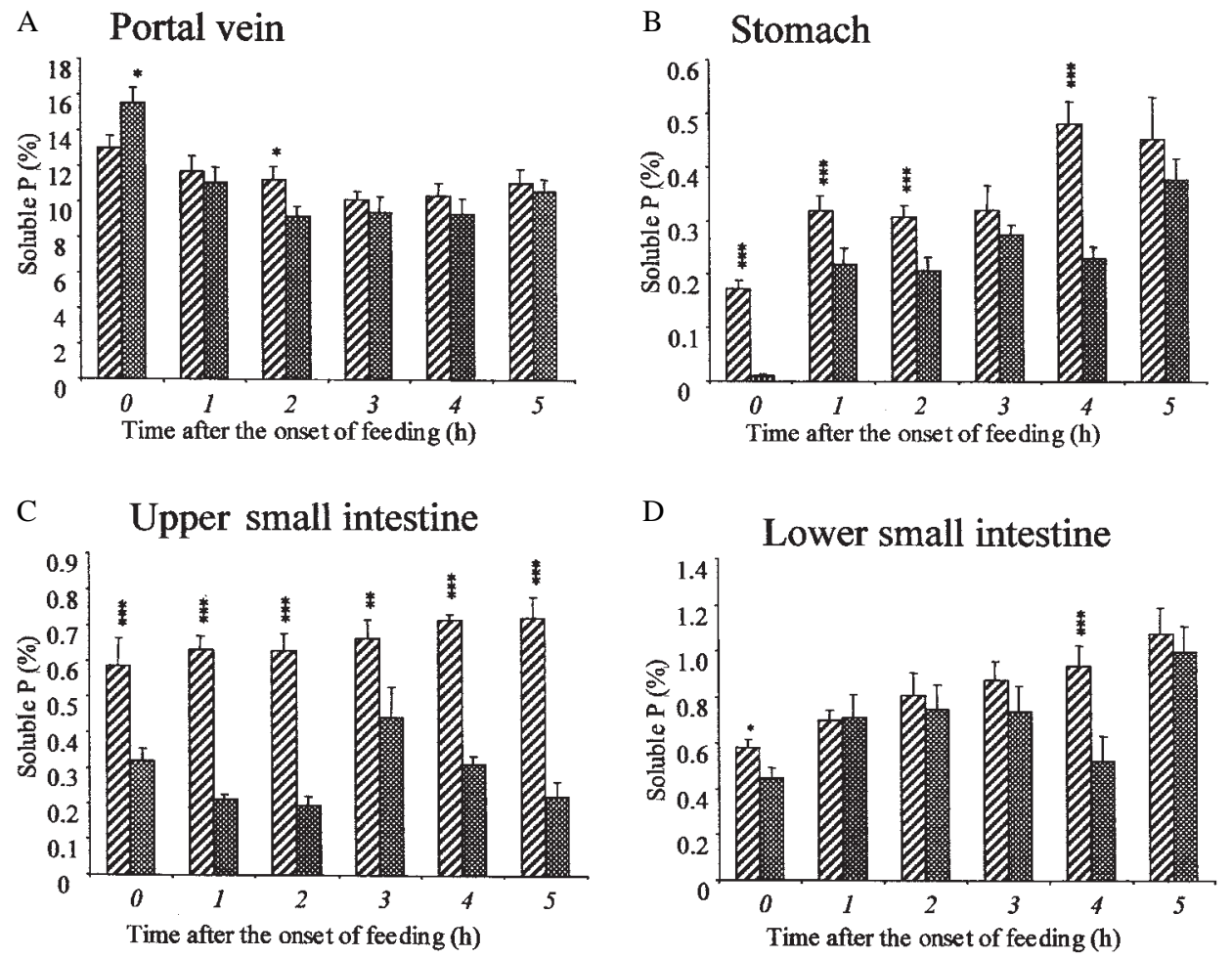

ZIA WPC

Figure 4. The effect of dietary protein digestion on soluble phosphorus levels. Values are means \pm SEM. The number of rats in each time point was five. $* p<0.05 ; * * p<0.01 ; * * * p<0.001$.

$(0 \mathrm{~h})$. This observation is in agreement with those of Fushiki et al. [17] who have reported a rapid gastric emptying and digestion of $\alpha$-la. Differences in gastric emptying, digestion and absorption of the two milk proteins are thought to be related to their structures. Several studies have related slow digestion of WPC diet to the resistance of $\beta$-la to peptic and pancreatic digestion $[33,39]$. It has been shown that the intramolecular disulfide bonds were known to stabilize the native structure of $\beta$-la by lowering the entropy of unfolded form of the chain [4] and that cleavage of the S-S bonds results in a significant increase of the susceptibility to peptic and pancreatic proteolysis.

Pepsin is known to cleave peptide bonds that involve amino acids with large hydrophobic side-chains, such as phenylalanine (Phe) and leucine [50]. The calculations on the three-dimensional structure of $\alpha$-la by Warme and co-workers [47], demonstrate a large hydrophobic area on the surface of the native $\alpha$-la molecule from which $\mathrm{Phe}_{31}$ protrudes into solution. This hydrophobic area of native $\alpha$-la molecule is more susceptible to proteolysis by pepsin. However, it has been also reported that $\alpha$-la undergoes a conformational change at $\mathrm{pH}$ lower than 4.0 to a denatured state of the molecule so that the rapid hydrolysis of this protein by pepsin does not necessarily depend on some particular hydrophobic area structure of native protein molecule [13].

Conformation changes of $\alpha$-la caused by isolation procedures could also have 
ZZA WPC

$\alpha-1 a$

A Stomach

B Upper small intestine

\section{Lower small intestine}

Figure 5. The effect of dietary protein digestion on insoluble phosphorus levels. Values are means \pm SEM. The number of rats in each time point was five. $* p<0.05$; $* * p<0.01 ; * * * p<0.001$.

increased the susceptibility of this protein to enzymatic hydrolysis by exposing hydrophobic groups which are usually buried inside the globular structure. Lieske and Konrad [24] have also reported that the degree of denaturation of $\alpha$-la could ease enzymatic degradation of $\alpha$-la by papain. The postulate that $\beta$-la has an increased resistance to proteolysis when it contains bound fatty acids is consistent with the
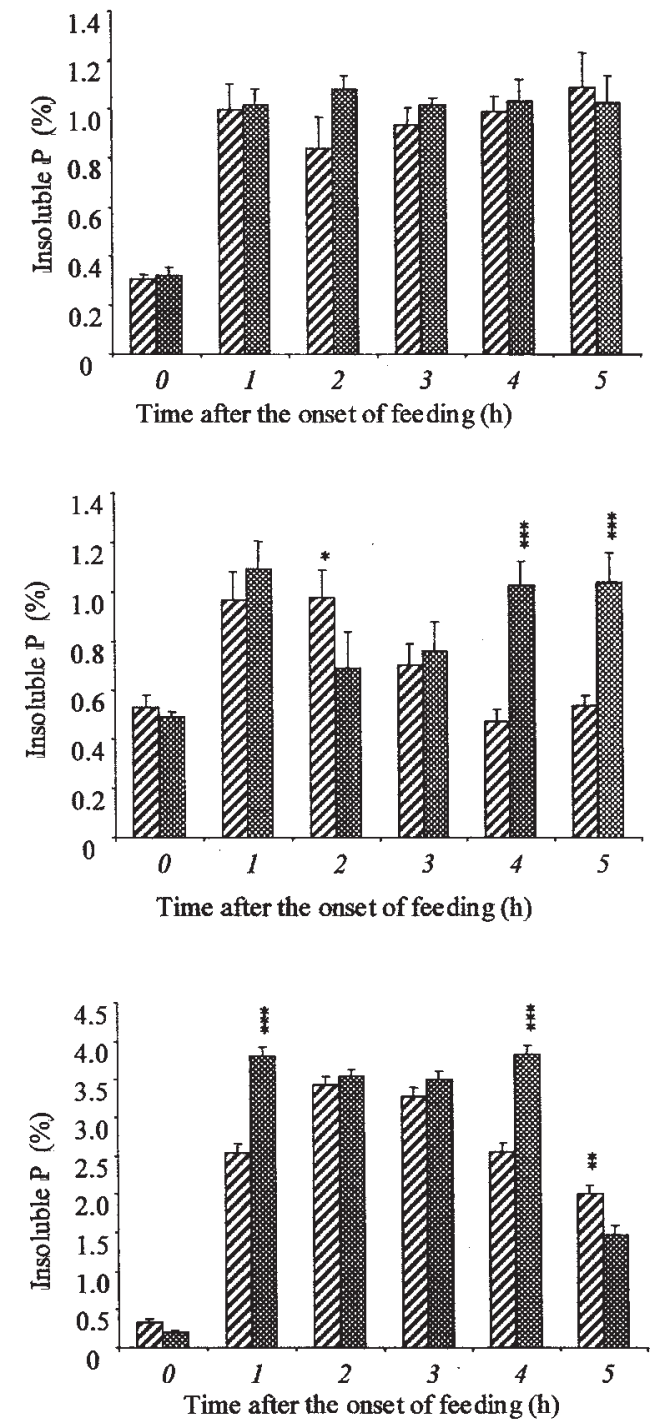

suggestion that the biological role of $\beta$-la is to facilitate the absorption of vitamin $\mathrm{A}$ and fatty acids [25, 31]. Results reported in the present investigation were in agreement with this concept as animals had been fed with an equilibrated diet which of course contained lipids brought by WPC source and added corn oil.

Although, this work showed significant differences in $\alpha$-amino acids levels in 
stomach and small intestinal contents, their values in portal vein were not statistically different. In a study with rats, Galibois et al. [18] have found no significant differences in total amino acids appearing in portal blood between casein meals (12\% and $24 \%)$ and rapseed proteins meal (12\%). The lack of significant differences in portal $\alpha$-amino acids levels could be related to many factors, including: the rate of gastric emptying which is recognized to have a direct control upon the amount of material released and absorbed in the small intestine [44]; the efficiency of proteolytic enzymes; the well-known competition and the mutual inhibition of sugars and amino acids for absorption sites [10, 34]; the rates and patterns of absorption of individual amino acids $[12,18]$ and the degree of blood clearance being the function of effective capture and utilization by the liver, gastrointestinal and peripheral tissues.

Also of interest are differences in the kinetics of soluble and insoluble calcium and phosphorus levels between WPC and $\alpha$-la. Calcium and phosphorus were not distributed and absorbed in the same patterns throughout the gut. The lower soluble calcium levels in the upper small intestine would be related to the active calcium absorption and to a rapid transit of digests [22]. Active transcellular calcium transport, independent from calcium concentration and mediated by calcitriol is thought to be predominant in the upper small intestinal jejunum and duodenum [3]. Small peptides released from whey proteins were known to be preferentially and rapidly absorbed in the upper small intestine [27]. Furthermore, these peptides can bind and solubilize calcium and phosphorus [20, 32, 48, 49] and then, enhance absorption of these minerals. For $\alpha$-la which is rapidly digested in the stomach and upper gut, such a mechanism could explain the slightly higher levels of portal $\mathrm{Ca}$ measured from 0 to $2 \mathrm{~h}$ after the onset of feeding. Previous findings have shown that $\mathrm{Ca}$ absorption is more efficient from 0 to $3 \mathrm{~h}$ with $\alpha$-la based diet compared to other milk protein sources including caseins, whey proteins and $\beta$-la [28].

For calcium, a concentration gradient between content of the lower part of the intestine and the blood content was observed, indicating that passive paracellular transport was mostly active in the jejunal and the ileum. Previous works have indicated that dietary calcium is absorbed mainly in the lower portion of the small intestine after a meal containing normal calcium concentration by moving passively across the gastrointestinal barrier [11, 26]. Indeed, as reported previously, the increase of soluble calcium concentration in the gut after meals would enhance calcium absorption in the lower intestine where passive transport takes place [22]. Bile salts would also be involved in higher soluble calcium and phosphorus concentration in the lower small intestine [2]. In contrast, the gradual formation of insoluble calcium-phosphates complexes in lower small intestine were mainly explained by the increase of $\mathrm{pH}$ in the lower gut as the digestion progresses. Highly available dietary phosphorus reduces the formation of insoluble metal-phosphate complexes in the intestine, particularly with calcium and magnesium [38]. Therefore, high soluble and $\alpha$-amino acids levels released by a slow digestion and absorption of WPC in the gastrointestinal tract of rats might have inhibited the formation of insoluble calcium-phosphorus complexes.

\section{CONCLUSION}

In conclusion, findings of the present study suggest that hydrolysis and absorption of $\alpha$-la might be faster than that of WPC. This study also showed that insoluble calcium, soluble and insoluble phosphorus levels are dependent of the nature of diet ingested, the sites and time of sample collections. Overall, results suggest that peptides released by rapid hydrolysis of $\alpha$-la would greatly influence the active transport process of calcium and phosphorus absorption, whereas those 
of WPC would later affect the passive transport system.

\section{ACKNOWLEDGEMENTS}

This study was supported by NOVALAIT and CRSNG.

\section{REFERENCES}

[1] Adibi S.A., Mercer D.W., Protein digestion in human intestine as reflected in luminal, mucosal and plasma amino acids concentrations after meals, J. Clin. Invest. 52 (1973) 1586-1594.

[2] Allen L.H., Calcium bioavailability and absorption: a review, Am. J. Clin. Nutr. 35 (1982) 783-808.

[3] Anderson J.J.B., Nutritional biochemistry of calcium and phosphorus, J. Nutr. Biochem. 2 (1991) 300-307.

[4] Anfinsen C.B., Scheraga, H.A., Experimental and theoretical aspects of protein folding, Adv. Protein Chem. 29 (1975) 205-299.

[5] Berliner L.J., Koga K., $\alpha$-lactalbumin binding to membranes: evidences for a partially buried protein, Biochem. 26 (1987) 3006-3009.

[6] Berliner L.J., Ellis P.D., Murakami K., Manganese (II) electron spin resonance and Cadmiun-113 nuclear magnetic resonance evidence for the nature of calcium binding site in $\alpha$-lactalbumins, Biochem. 22 (1983) 5063-5068.

[7] Berliner L.J., Meinholtz D.C., Hirai Y., Musci G., Thompson M.P., Functional implications resulting from disruption of the calcium-binding loop in bovine $\alpha$-lactalbumin, J. Dairy Sci. 74 (1991) 2394-2402.

[8] Cheftel J.-C., Cuq J.-L., Lorient D., Protéines alimentaires, Lavoisier. Tech \& Doc, Paris, 1985, pp. 156-192.

[9] Church F.C., Swaisgood H.E., Porter D.H., Catignani G.L., Spectrophotometric assay using Ophthaldialdehyde for determination of proteolysis in milk and isolated milk proteins, J. Dairy Sci. 66 (1983) 1219-1227.

[10] Cook G.C., Impairment of glycine absorption by glucose and galactose in man, J. Physiol. 218 (1971) 61-71.

[11] Cramer C.F., Copp D.H., Progress and rate of absorption of radiostrontium through intestina tracts of rats, Proc. Soc. Exp. Biol. Med. 102 (1959) 514-517.

[12] Dent C.E., Schilling J.A., Studies on the absorption of proteins: the amino acid pattern in the portal blood, Biochem. J. 44 (1949) 318-332.

[13] de Wit J.N., Klarenbeek G., Effect of various heat treatments on structure and solubility of whey proteins, J. Dairy Sci. 67 (1984) 2701-2710.
[14] Fersht A., Enzymes: structure and mechanism, Freedman and Co., San Francisco, 1977.

[15] Fiske C.H., Subbarow U., The colorimetric determination of phosphorus, J. Biol. Chem. 66 (1925) 375-400.

[16] Freund R.J., Littel R.C., Spector P.C., SAS system for linear models, SAS Institute Inc., Cary, NC, USA, 1986.

[17] Fushiki T., Yamamoto N., Naeshiro I., Iwai K., Digestion of $\alpha$-lactalbumin in the rat gastrointestinal tracts, Agric. Biol. Chem. 50 (1986) 95-100.

[18] Galibois I., Nunes C.S., Rerat A., Savoie L. Net appearance of amino acids in portal blood during the digestion of casein or rapseed proteins in the pig, Can. J. Physiol. Pharmacol. 67 (1989) 1409-1417.

[19] Hagemeister H., Antila P., Oro-ileal digestibility of homoarginine-labelled $\beta$-lactoglobulin and casein in adult miniature pigs, J. Anim. Physiol. Anim. Nutr. 72 (1994) 86-91.

[20] Hall T.C., Lehmann H., Experiments on the practicability of increasing calcium absorption with protein derivatives, Biochem. 38 (1944) 117-119.

[21] Kronman M.J., Characteristics of the binding of $\mathrm{Ca}^{2+}$ and other divalent metal ions to bovine $\alpha$-lactalbumin, J. Biol. Chem. 25 (1981) 8582-8587.

[22] Lee Y.S., Noguchi T., Naito H., An enhanced intestinal absorption of calcium in the rat directly attributed to dietary casein, Agric. Biol. Chem. 43 (1979) 2009-2011.

[23] Lee Y.S., Noguchi T., Naito H., Phosphopeptides and soluble calcium in small intestine of rats given a casein diet, Br. J. Nutr. 43 (1980) 457-467.

[24] Lieske B., Konrad G., Interrelation between $\mathrm{pH}$ and availability of $\alpha$-lactalbumin and $\beta$-lactoglobulin for proteolysis by papain, Int. Dairy J. 6 (1996) 359-370.

[25] MacLeod A., Fedio W.M., Chu L., Ozimek L. Binding of retinoic acid of $\beta$-lactoglobulin variants A and B: Effect of peptic and tryptic digestion on the protein-ligand complex, Milchwissenschaft. 51 (1996) 3-7.

[26] Marcus C.S., Lengemann F.W., Absorption of $\mathrm{Ca}^{45}$ and $\mathrm{Sr}^{85}$ from solid and liquid food at various levels of the alimentary tract of rat, J. Nutr. 77 (1962) 155-160.

[27] Matthews D.M., Adibi S.A., Peptide absorption, Gastroenterology 71 (1976) 151-161.

[28] Pantako T.O., Passos M., Desrosiers T., Amiot J., Effet des protéines laitières sur l'absorption de $\mathrm{Ca}$ et $\mathrm{P}$ mesurée par les variations temporelles de leurs teneurs dans l'aorte et la veine porte chez le rat, Int. Dairy J. 4 (1994) 37-38.

[29] Papiz M.Z., Sawyer L., Eliopoulos E.E., North A.C.T., Findlay J.B.C., Sivaprasadarao R., Jones J., Newcomer M.E., Kraulis P.J., The structure of $\beta$-lactoglobulin and its similarity to plasma retinol-binding protein, Nature 324 (1986) 383-385. 
[30] Patocka G., Jelen P., Calcium association with isolated whey proteins, Can. Inst. Food Sci. Technol. J. 24 (1991) 218-223.

[31] Puyol P., Perez M.D., Ena M.J., Calvo M., Effect of retinol and fatty acid binding by bovine $\beta$-lactoglobulin on its resistance to trypsin digestion, Int. Dairy J. 3 (1993) 589-597.

[32] Raven A.M., Lengemann F.W., Wasserman R.H., Studies of the effect of lysine on the absorption of radiocalcium and radiostrontium by the rat, J. Nutr. 72 (1960) 29-36.

[33] Reddy M.I., Navin K.D.K., Kinsella J.E., Structural and conformational basis of the resistance of $\beta$-lactoglobulin to peptic and chymotryptic digestion, J. Agric. Food Chem. 36 (1988) 737-741.

[34] Reiser S., Christiansen P.A., Intestinal transport of amino acids as affectd by sugars, Am. J. Physiol. 216 (1969) 915-924.

[35] Sato R., Noguchi T., Naito H., The necessity for the phosphate portion of casein molecules to enhance $\mathrm{Ca}$ absorption from the small intestine, Agric. Biol. Chem. 47 (1983) 2145-2147.

[36] Sato R., Noguchi T., Naito H., Casein phosphopeptides (CPP) enhance calcium absorption from the small ligated Segment of rats small intestine, J. Nutr. Sci. Vitaminol. 49 (1986) 2009-2011.

[37] Scanff P., Savalle B., Miranda G., Pélissier J.-P., Guilloteau P., Toullec R., In vivo digestion of milk proteins. Effect of technological treatments, J. Agric. Food Chem. 38 (1990) $1623-1630$

[38] Schaafsma G., Rolls B.A., Blakeborough P., Effects of milk versus plant proteins on bioavailability of micronutrients, Bull. of the IDF 253 (1990) 55-60.

[39] Schimidt D.G., Poll J.K., Enzymatic hydrolysis of whey proteins. Hydrolysis of $\alpha$-lactalbumin or $\beta$-lactoglobulin in buffer solutions by proteolytic enzymes, Neth. Milk Dairy J. 45 (1991) 240-255.

[40] Stuart D.I., Acharya K.R., Walker N.P.C., Smith S.G., Lewis M., Phillips D.C., $\alpha$-lactalbumin possesses a novel calcium binding loop, Nature 324 (6092) (1986) 84-87.

[41] Takada Y., Aoe S., Kumegawa M., Whey protein stimulates the proliferation and the differentiation of osteoblast MC3T3-E1 cells, Biochem. Biophys. Res. Commun. 223 (1996) 445-449.

[42] Takada Y., Yahiro M., Nakajima I., Effect of milk components on calcium absorption and bone metabolism, in: Yamauchi K., Imamura T., Morita T. (Eds.), Kouseikan, Tokyo, 1993, Characterization of milk component and health, pp. 171-185.

[43] Takada Y., Kobayashi N., Matsuyama H., Kato K., Yamamura J., Yahiro M., Kumegawa M. Aoe S., Whey proteins suppresses the osteoclast-mediated bone resorption and osteoclast celle formation, Int. Dairy J. 7 (1997) 821-825.

[44] Yvon M., Pélissier J.-P., Characterization and kinetics of evacuation of peptides resulting from casein hydrolysis in the stomach of the calf, J. Agric. Food Chem. 35 (1987) 148-156.

[45] Yvon M., Van Hille I., Pélissier J.-P., Guilloteau P., Toullec R., In vivo milk digestion in the calf abomasum. II. Milk and whey proteolysis, Reprod. Nutr. Dev. 24 (1984) 835-843.

[46] Ziegler E.E., Formon S.J., Lactose enhances mineral absorption in infancy, J. Pediat. Gastroenterol. Nutr. 2 (1983) 288-294.

[47] Warme P.K., Momany F.A., Rumball S.V., Tuttle R.W., Scheraga H.A., Computations of structures homologous proteins. $\alpha$-lactalbumin from lysozyme, Biochemistry 13 (1974) $768-782$

[48] Wasserman R.H., Comar C.L., Nold M.M., The influence of amino acids and other organic compounds on the gastrointestinal absorption of calcium $^{45}$ and strontium ${ }^{89}$ in the rat, J. Nutr. 58 (1956) 371-383.

[49] Wasserman R.H., Comar C.L., Schooley J.C. Lengemann F.W., Interrelated effects of L-lysine and other dietary factors on the gastrointestinal absorption of calcium ${ }^{45}$ in the rat and chick, J. Nutr. 62 (1957) 367-376.

[50] Webb E.C., Enzyme nomenclature, IUB MB Academic Press, New York, 1992, 403.

To access this journal online: www.edpsciences.org 